\title{
Medisinens kirurgisering og etableringen av en norsk legeskole i 1814
}

\begin{abstract}
Sammendrag
Den norske legeutdanningen ble etablert i 1814 som en kombinert utdanning i medisin og kirurgi. Det gjorde den norske legeutdanningen relativt unik på den tiden og etablerte universitetet som en sentral arkitekt i danningen av en forent profesjon av medisin og kirurgi.
\end{abstract}

I andre europeiske land lot en slik universitetsbasert medisinskkirurgisk utdanning vente på seg vesentlig fordi det allerede fantes kirurgiske legeskoler, og fordi kirurgiske og medisinske eliter ikke ønsket å forene medisin og kirurgi til én profesjon.

Fra sent på 1700-tallet syntes imidlertid en forent utdanning rasjonell av flere grunner. Den kirurgiske utdanningen var blitt vitenskapelig, de medisinske eliter hadde akseptert kirurgenes kliniskanatomiske tilnærming til sykdom, og opplysningstidens ideer favoriserte en nyttig legeutdanning som kunne tjene samfunnets behov for en mer praktisk, kirurgisk medisin.

Når disse faktorene fikk innflytelse i Norge i begynnelsen av 1800-tallet, må det ses i sammenheng med at landets første legeutdanning kunne etableres på bar bakke. Viktig var det også at det allerede eksisterte flere stillinger for kirurger enn for medisinere, slik at en ren medisinskole ikke var aktuelt.

\section{Per Haave}

per.haave@iakh.uio.no

Markusveien 13

3041 Drammen

I 1812 ble det bestemt at legeutdanningen ved Det Kongelige Frederiks Universitet skulle etableres som et medisinskkirurgisk studium. Dermed fikk Det medisinske fakultet «en langt større Virkekreds, end den, der er de medicinske Faculteter i andre Lande foreskreven» (1, s. 594). Ifølge professor Michael Skjelderup (1769-1852) ble løsningen lagt merke til: «Udlandet vogter paa vort medicinske Facultet, hvorlunde det er istand til at danne Læger lige duelige i Medicin og Chirurgie, uden ligesom $\mathrm{i}$ andre Lande, at vorde understøttede af egne Læreanstalter for Chirurgien» (1, s. 581-2).

Da undervisningen ved Det medisinske fakultet startet høsten 1814, var Norge det eneste landet i Europa med en universitetsutdanning som ikke skilte mellom medisinere og kirurger. Belgia fulgte etter i 1835 , deretter Danmark (1842), Preussen (1852), Sverige (1861) og Østerrike (1872), for å nevne noen. Derimot var medisin og kirurgi integrert i flere skoler utenfor universitetene, blant annet ved kirurgiske akademier. Et tidlig eksempel er Collegium Medico-Chirurgicum som ble opprettet i Berlin i 1725 (2). Mest kjent er de franske helseskolene (écoles de santé), som i 1794 erstattet universitetene og de kirurgiske læreanstaltene som ble stengt etter revolusjonen i 1789 (3).

Det er med andre ord ikke foreningen av medisin og kirurgi, men den forente undervisningens universitetsforankring som gjorde den norske legeutdanningen unik på begynnelsen av 1800-tallet. Norge skilte seg også ut ved at landets eneste legeskole ble lagt til universitetet. I Europa for øvrig spilte universitetene en dominerende rolle bare i de tyske statene, men selv ikke der var de enerådende. Først mot slutten av 1800-tallet, etter lenge å ha vært spredt på offentlige og private skoler - så vel militære som sivile - med og uten tilknytning til sykehus, ble legeutdanningen i Europa gjennomgående et universitetsanliggende. I 1896 ble det også gjenreist en universitetsutdanning for leger i Frankrike (4).

\section{Fra to yrker til ett}

I Europa hadde medisin og kirurgi skilt lag i middelalderen. Medisinen ble etablert som en teoretisk universitetsdisiplin for samfunnets sosiale eliter, mens kirurgien tok form som et laugorganisert barberyrke med utøvere fra lavere samfunnslag (5). I Danmark-Norge ble skillet institusjonalisert etter opprettelsen av Københavns medisinske fakultet i 1537. Da hadde kirurgene allerede etablert en håndverksutdanning i regi av kongelig sanksjonerte barberlaug. Barberkirurgene fikk en privilegert stilling $i$ et marked med mange forskjellige yrkesutøvere, idet bare laugmedlemmer rettmessig kunne praktisere kirurgi. Etter hvert fikk barberkirurger som regel ansvaret for all legekunst i hær og flåte. Dermed opparbeidet de seg en medisinsk kompetanse som også ble etterspurt i det sivile samfunnet. Den medisinske eliten i København så med mistro på barberkirurgenes medisinske virke og sørget for at kongemakten definerte grensene for medisinsk og kirurgisk praksis, først i København (1619), dernest $i$ hele riket (1672) (6-8).

Fra 1700-tallet og utover nærmet medisin og kirurgi seg hverandre på ulike nivåer i praksis, lovgivning og utdanning. Etableringen av en enhetlig utdanning var skjellsettende, fordi medisinere og kirurger fikk en felles kunnskapsbase som gjorde det mulig å bygge et «moderne» profesjonsfellesskap (9).

Foreningen av medisinsk og kirurgisk utdanning foregikk i to faser. Den første ble innledet i Frankrike tidlig på 1700-tallet og er fremfor alt kjennetegnet ved at kirurgiske skoler ga undervisning i medisinske fag som materia medica, patologi og terapi. Den andre fasen, med etablering av en felles medisinsk og kirurgisk universitets-

\section{Hovedbudskap}

- Fra middelalderen inntil 1800-tallet var medisin og kirurgi to forskjellige fag med forskjellige typer utdanning og status

- I 1814 ble medisin og kirurgi integrert i medisinstudiet ved Norges nye universitet

- Sentrale argumenter ble hentet fra opplysningstidens krav om vitenskapens sosiale nytte

- En forutsetning var kirurgiens nye rolle som praktisk vitenskap 
utdanning, ble innledet i Norge på begynnelsen av 1800-tallet. Først i denne fasen opphørte medisin og kirurgi formelt å være to ulike yrker. De franske helseskolene fra 1794 inntok en særstilling ved at de erstattet både de kirurgiske skolene og medisinske fakultetene.

\section{Kirurgiens akademisering}

Løsrivelsen fra barberyrket er et karakteristisk trekk ved kirurgiens utvikling på 1700tallet. Franske kirurger gikk foran i forsøket på å etablere kirurgi som en selvstendig profesjon med en standardisert, vitenskapelig utdanning (9).

Den franske reformbevegelsen fikk tidlig nedslag i Danmark-Norge. Vel ti år etter opprettelsen av den første kirurgiskolen i Paris ble det etter fransk forbilde opprettet en kirurgisk statsskole i København i 1736 (10). Fem lærere holdt offentlige demonstrasjoner og forelesninger i anatomi og kirurgi $i$ et auditorium med plass til 200 personer. Etter hvert ble det holdt kliniske demonstrasjoner for kirurger ved Det Kongelige Frederiks Hospital, som ble opprettet i 1756 med den kirurgiske eliten som pådriver. Praksisopplæringen fortsatte imidlertid som en håndverksutdanning i barberstuene, men under skolens kontroll. Det hele ble avsluttet med en offentlig eksamen. Skolens sjef - med tittelen generalkirurg fikk også det administrative ansvaret for all kirurgi i unionen $(10,11)$.

I 1785 ble den kirurgiske statsskolen i København omdannet til et kongelig kirurgisk akademi med tre professorer, fire reservekirurger og én kjemilærer. Det ble reist en ny bygning med kjemisk laborato- rium, auditorium, instrumentsamling, disseksjonsstue, møtesal og bibliotek. Nå ble også praksisopplæringen flyttet fra barberstuene til akademiet og hospitalet. Dermed ble utdanningen helt uavhengig av barberlaugene. Samtidig ble barberkirurgenes rettigheter innskrenket $(12,13)$.

Det kirurgiske akademiet underviste også i teoretisk og praktisk medisin, og tross motstand fra den medisinske eliten, fikk akademikirurgene rett til å praktisere medisin uten å måtte avlegge en universitetsprøve i medisinske fag, en ordning som var blitt innført i 1774. Dermed ble kirurgiutdanningen også helt uavhengig av det medisinske fakultet.

Med akademiet skapte den kirurgiske eliten i København en standardisert utdanning som omformet kirurgien fra et empirisk håndverk til en eksperimentell vitenskap festet til anatomisk og fysiologisk kunnskap samtidig som det omfattet tradisjonelle medisinske fag. Det gjenspeilte en allmenn utvikling i Europa $(9,14)$.

\section{En ledende legeskole}

Det kirurgiske akademiet i København ble raskt en mer populær legeskole enn byens medisinske fakultet. I perioden 1786-1808 ble det $i$ alt eksaminert 55 medisinere og 290 kirurger. Akademiets popularitet hadde flere årsaker. Utdanningen var mer praktisk og dermed sosialt mer nyttig enn den teoretiske medisinerutdanningen. Akademikirurgene fikk rett til å behandle alle slags sykdommer, mens medisinerne måtte holde seg til de (indre)medisinske. Dessuten var akademiet åpent for alle. Fakultetet tok bare imot latinskolens elever med studenteksamen $(13,15,16)$.

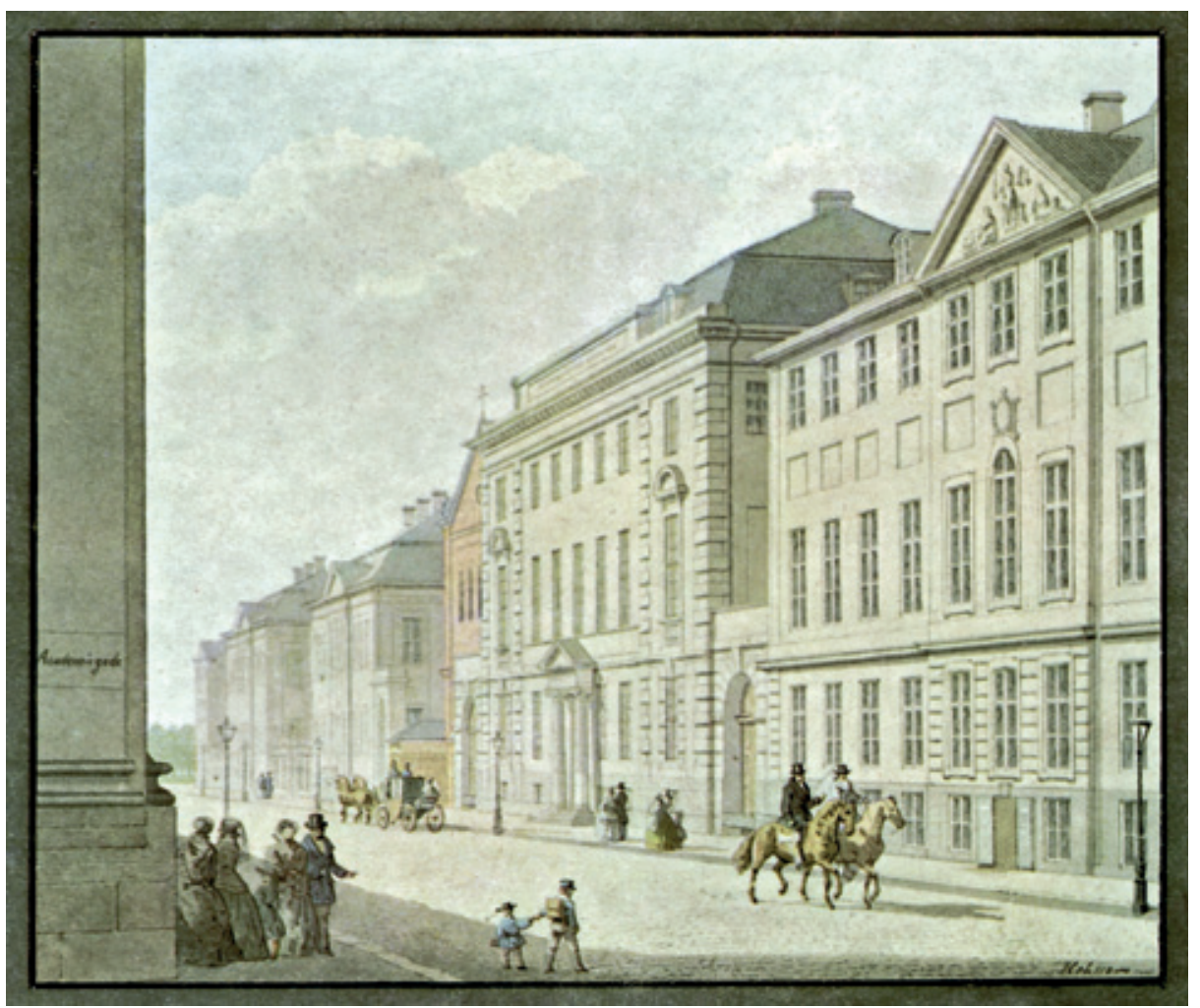

Akademiets popularitet nådde også de høyere sosiale lagene. Fra begynnelsen av 1790 -årene valgte et raskt økende antall «studerte» den kirurgiske veien til legegjerningen, og flere medisinske kandidater avla eksamen ved akademiet. Dette synes å gjenspeile en allmenn oppvurdering av praktisk kunnskap. På denne måten ble også det sosiale skillet mellom medisinere og kirurger langt på vei visket ut $(13,15,16)$.

Flere akademikirurger tok på eget initiativ medisinsk embetseksamen, som var blitt innført i 1788. Inntil da hadde det medisinske fakultet som regel bare gitt praksisrett til kandidater med doktorgraden. Mange kirurger hadde således en bredere kompetanse enn leger som bare var utdannet og eksaminert av fakultetet. I det hele tatt ble kirurgene den mest etterspurte legegruppen. Eksempelvis ble de tildelt en større rolle enn medisinerne under arbeidet med å bekjempe radesyken i Norge på slutten av 1700-tallet (17). Det ble også opprettet flere sivile embeter for kirurger enn medisinere. I 1814 besto det sivile legevesenet i Norge av 27 kirurgikater og 15 fysikater. Enkelte steder ble fysikater også erstattet med kirurgikater (18). «Erfaringen har lært, at almuen er i almindelighed mere tjent med en kirurg end med en medicus, da den ugerne og uden tillid samt sjældent søger indvortes hjælp, men hellere kirurgiske lægemidler,» uttalte generalkirurgen i København da det i 1802 var snakk om å bytte ut et fysikat i Arendal med to distriktskirurgikater (13, s. 158).

\section{Medisinere og kirurger i konflikt}

Kirurgiens akademisering og voksende samfunnsmessige betydning herdet den medisinske eliten til motstand. Mange konflikter handlet om det administrative ansvaret for kirurgien. I 1740 lyktes det medisinerne å få overført ansvaret fra generalkirurgen, sjefen for den kirurgiske statsskolen, til det nye Collegium Medicum Regium - det første sunnhetskollegiet i Danmark-Norge som frem til 1774 bare hadde medisinerne som faste medlemmer. Kirurgene kjempet på sin side for å gjenerobre sin administrative makt, og klarte i 1785 å få lagt ansvaret til det nyetablerte akademiet. Den administrative todelingen skapte medisinalpolitiske vansker. En samling tvang seg frem. I 1803, da Collegium Medicum ble avløst av Det kongelige Sundheds-Collegium, som fikk en norsk av paviljongene til Det Kongelige Frederiks Hospi tal. Den nye akademibygningen ligger midt i bildet Reproduksjon avakvarell av H.G.F. Holm, ca. 1845. Steno Museet, Aarhus Universitet 


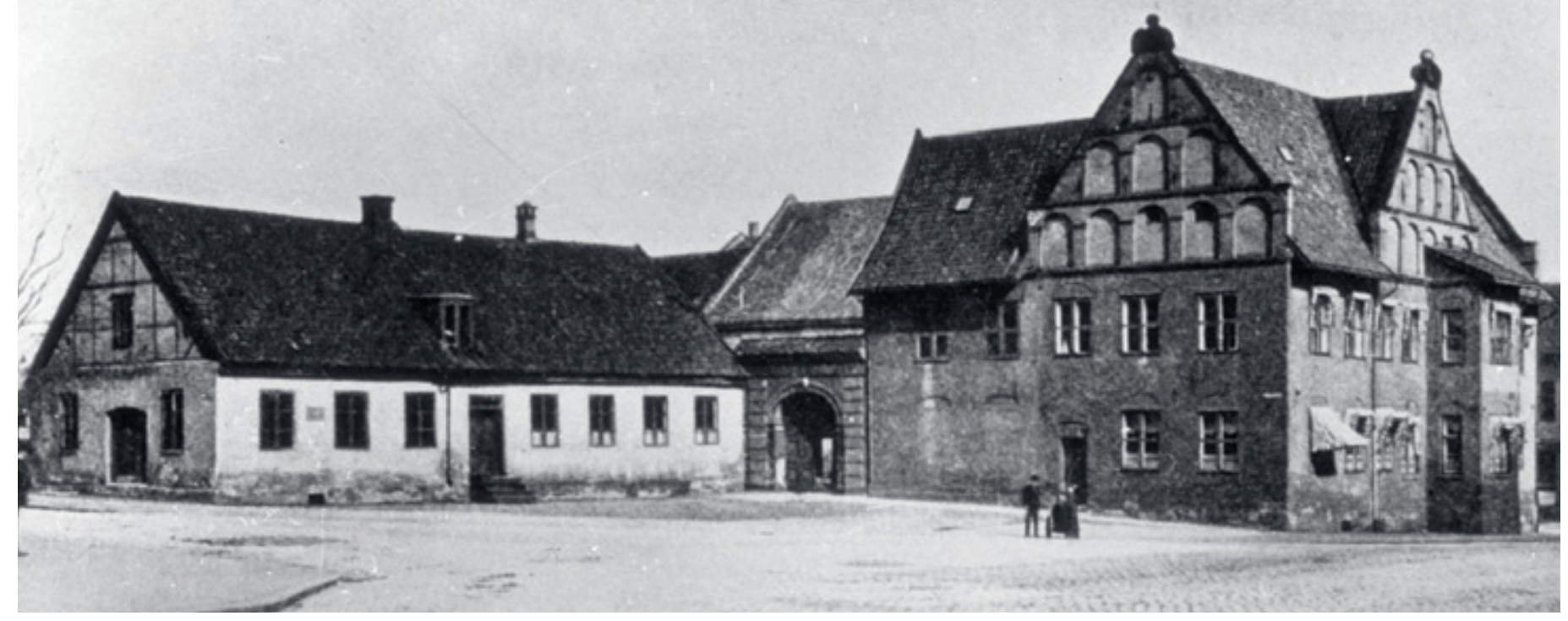

Anatomiundervisningen inntok en sentral plass i den medisinskkirurgiske legeutdanningen. I Norge ble denne undervisningen påbegynt i Mangelsgården i Storgaten i februar i 1815. Fra høsten 1815 til 1852 fant den sted ved Christiania torv, i Brænderigaarden (til venstre) der professor Michael Skjelderup lyktes å innrede «et ordentlig Anatomie-Kammer»

avlegger i 1809, ble det administrative ansvaret for medisin og kirurgi samlet i én etat. Dette fikk imidlertid ingen konsekvenser for legeutdanningen $(7-8,10-13)$.

Siden midten av 1700-tallet hadde det medisinske fakultet ansatt flere ledende kirurger, men de mange forsøkene på å legge kirurgiutdanningen under fakultetet, førte ikke frem. Den kirurgiske eliten strittet imot. I 1774 kokte et omfattende reformforsøk fra 1771 ned til en bestemmelse om at kirurger som skulle praktisere medisin, måtte avlegge nevnte prøve i medisinske fag ved fakultetet, en ordning som altså ble avskaffet da kirurgene styrket sin posisjon i 1785 . Da krigen brøt ut i 1807, bidro behovet for kirurger til å befeste akademiet som en mer nyttig læreanstalt enn fakultetet. I det hele tatt kjempet medisinerne på vikende front $(7-8,10-13)$.

I 1808 ville regjeringskollegiet Den Kongelige Direction for Universitetet og de Lærde Skoler vite hvorfor fakultetets forelesninger ble fulgt av så få studenter - det var sjelden mer enn fire tilhørere. Fakultetets fem ansatte, hvorav tre med kirurgisk eksamen, blant dem Michael Skjelderup, beklaget at akademiets opprettelse hadde ført til en «flukt» bort fra fakultetet. Det var nok en overdrivelse, fordi studenttallet var lavt også før opprettelsen av akademiet. Videre mente de å vite at akademiets studenter utviste en «tiltagende ligegyldighed for visse av lægevidenskabens grene», samtidig som fakultetet ikke kunne kontrollere deres medisinske «duelighed». Professorene slo skuffet fast at fakultetet var «en i virkekreds højst indskrænket foranstaltning». Derfor var det på tide å oppheve skillet mellom medisinsk og kirurgisk utdanning og erstatte titlene «medicus» og «chirurgicus» med «læge». Da ville også alle embeter - de fleste var forbeholdt kirurger - stå åpne for «enhver videnskabelig læge», slik som i Frankrike etter at nye regler for autorisasjon var blitt innført ved lov i 1803. I det hele tatt ville fakultetet ha en sammenslåing på medisinens premisser - kirurgene skulle bli mer «dannede til alle lægers fælles forretninger» (16, s. 112-6). Forslaget fikk imidlertid ingen betydning i forste omgang (15).

\section{Den norske løsningen}

I Norge var det lenge delte meninger om medisin skulle være et fag ved et norsk universitet. Under den nasjonale universitetskampanjen i første halvdel av 1790-årene avviste landfysikus Hans Iver Horn (1761-1836) i Jarlsberg grevskap tanken om en fullstendig legeutdanning. Norge hadde altfor få sykehus og legeembeter og en befolkning som i liten grad etterspurte legetjenester. I beste fall kunne et universitet tilby en forberedende undervisning i naturhistorie, anatomi og fysiologi for studenter som ville utdanne seg i København (19). Den Kongelige Direction for Universitetet og de Lærde Skoler inntok samme standpunkt våren 1811 (20).

Landfysikus dr.med. Hans (Johannes) Møller (1736-96) i Bratsberg amt så det annerledes. I 1793 besvarte han en prisoppgave om hvordan et universitet burde utformes. Møller vant ingen pris, men publiserte planen i 1795 (21).

Møller mente at medisinstudiet burde innrettes som en felles teoretisk og kliniskanatomisk undervisning for medisinere og kirurger. Alle «nyttige» og «store» leger skulle skoleres i anatomi, eksperimentell fysikk, matematikk, naturhistorie og kjemi.
Fordi kirurgi i Møllers øyne utgjorde en selvfølgelig og nødvendig del av medisinen, måtte fakultetet ikke bare undervise i teoretisk kirurgi, men med hjelp av «en habil chirurgisk Operatør» også utdanne dugelige «Haandlæger» (21, s. 31).

Møller la stor vekt på at undervisningen skulle være praktisk. Derfor gjorde han disseksjon og klinisk undervising til en selvfølgelig del av legeutdanningen. Muligheten for klinisk undervisning i sykehus var riktignok begrenset, men ved å ta studentene med på kliniske besøk hjemme hos «chroniske Syge» en gang i uken, kunne professorene «give Candidaterne god Indsigt i den praktiske Lægekunst» (21, s. 30).

Da det i 1812 ble avgjort at et norsk universitet skulle legges til Christiania, ble det bestemt at det skulle etableres et fullstendig «medicinsk-chirurgisk Studium» (22-24). Vedtaket ble begrunnet med at byen hadde tre sykehus og dermed muligheter for klinisk undervisning. Selv om det ikke ble henvist til Møllers plan, trakk flere forhold $i$ retning av en fellesundervisning. Det var neppe økonomisk mulig å etablere to legeskoler, og det var heller ikke aktuelt å etablere en ren medisinsk utdanning, fordi det var opprettet flere kirurgiske enn medisinske embeter. Dessuten kunne det ikke forventes at nordmenn ville reise til København for å bli kirurger. Siden fakultetets fremste oppgave var å dekke landets behov for offentlige leger, måtte virkekretsen nødvendigvis bli «heel og ubeskaaren», kommenterte professor Michael Skjelderup noen år senere $(25, \mathrm{~s} .202)$.

Den norske løsningen var helt klart i samsvar med Skjelderup og den medisinske elitens tidligere ønske om å forene medisinsk og kirurgisk utdanning. En 
medisinskkirurgisk universitetsutdanning var likevel ingen selvfølgelig løsning på begynnelsen av 1800-tallet.

\section{Ingen selvfølgelig løsning}

Frankrike hadde på mange måter vist vei med etableringen av helseskolene i Paris, Montpellier og Strasbourg i 1794. Da Napoleonskrigene var over, ønsket imid- lertid den kirurgiske eliten i Frankrike å gjenreise kirurgien som en selvstendig profesjon med egen utdanning, mens medisinere så med mistro på sammenslåingen. Kampen for å skille medisinsk og kirurgisk utdanning toppet seg i 1815, men uten at det lyktes å gjenreise det forrevolusjonære systemet med atskilte utdanninger (26). I de tyske statene avviste store deler av

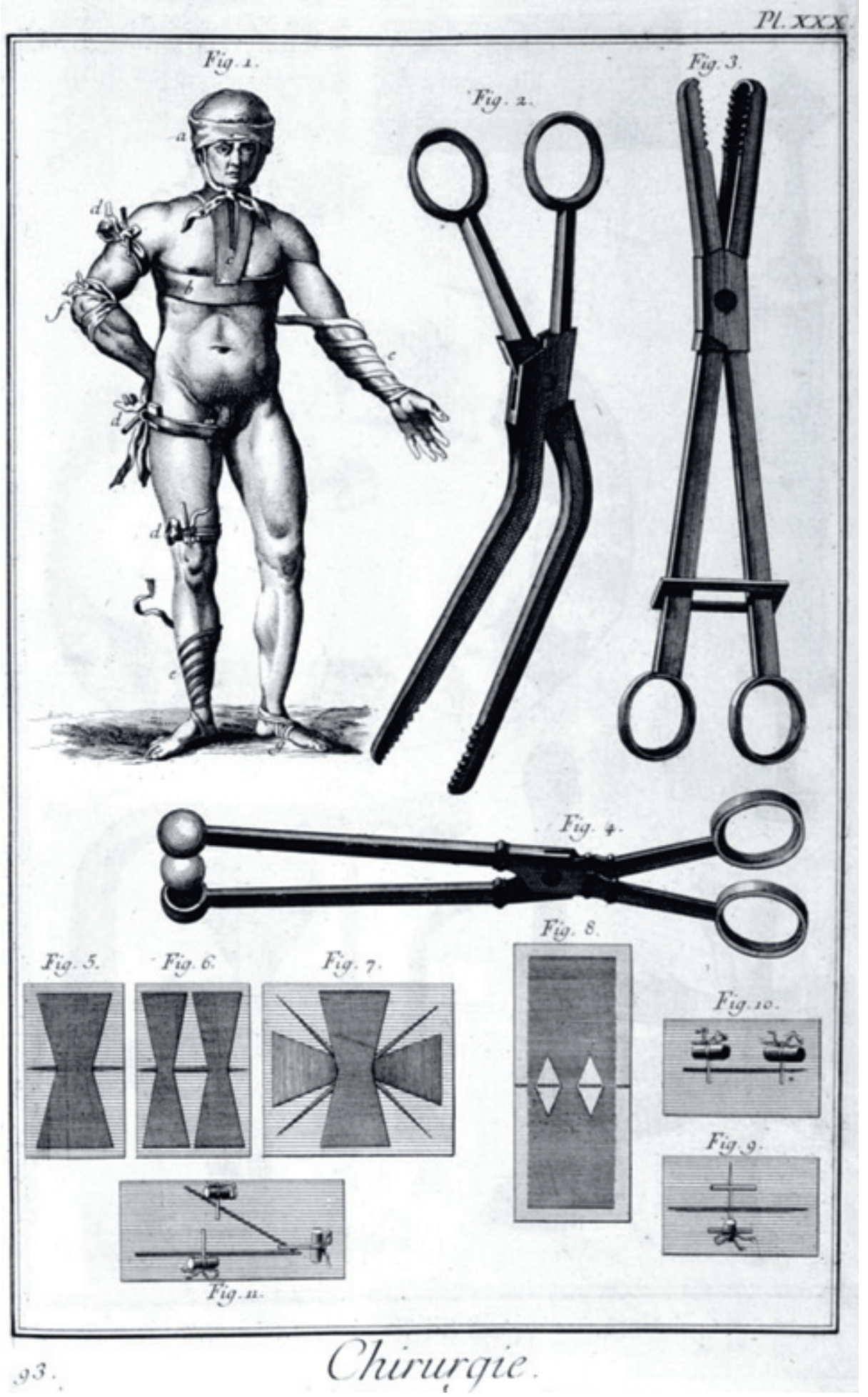

I opplysningstiden ble kirurgi et forbilde for en praktisk og samfunnsnyttig legegjerning. Den franske encyklopedien - Encyclopédie ou Dictionnaire raisonné des sciences, des arts et des métiers med Denis Diderot (1713-84) og Jean le Rond d'Alembert (1717-83) som redaktører - brakte mange illustrasjoner av kirurgiske instrumenter og kirurgisk praksis. Illustrasjon (c) Art Media, Heritage/SCANPIX

den medisinske eliten en sammenslåing av medisinsk og kirurgisk utdanning og beklaget at så mange kirurger avla medisinsk eksamen ved de medisinske fakultetene (2).

I Danmark forsøkte den kirurgiske eliten lenge å bevare akademiet som en selvstendig legeskole, men fra begynnelsen av 1800-tallet ble akademiets medisinske undervisning stadig oftere kritisert for å være mangelfull. Trolig gikk derfor flere «studerte» i stedet til fakultetet, især etter at øvelser i disseksjon og praktisk kirurgi ble innført rundt 1820. Men også fakultetets undervisning lot mye tilbake å ønske, ble det hevdet i ukebladet Kiøbenhavns Skilderie i 1826. I en serie artikler ble det presentert brev fra de påstått beste legeskolene i utlandet, blant annet Det medisinske fakultet i Christiania. Det første brevet kom da også fra Norge. Det var trolig skrevet av professorene - og akademikirurgene Michael Skjelderup og Magnus Thulstrup (1769-1844). Den medisinske eliten i København fulgte opp med et nytt krav om en felles medisinskkirurgisk utdanning, og den kirurgiske eliten måtte etter hvert gi tapt. Fra 1838 kunne verken medisinere eller kirurger få praksisrett uten en felles medisinskkirurgisk eksamen. Fire år senere ble akademiet og fakultetet slått sammen til et «lægevidenskabelig» fakultet ved Københavns universitet $(15,16)$.

Gamle strukturer i legeutdanningen i København var med andre ord ikke brutt ned da planen om et medisinstudium i Norge ble lagt i 1812. Det norske studiet kunne imidlertid bygges fra grunnen av. Det gjorde det mulig å realisere en tanke som den medisinske eliten i København lenge, men forgjeves, hadde kjempet for. Resultatet ble et kombinert medisinskkirurgisk studieopplegg med vitenskapelig fundert praksis som mål (27). Tanken som ble brakt frem til seier i Norge, bygde i siste instans på undervisningen ved det kirurgiske akademiet i København. Det samme gjaldt det legevitenskapelige fakultetet som ble opprettet i København i $1842(15,16)$. Hvorfor kom kirurgien til å øve en slik innflytelse?

\section{«Kirurgisering» og nyttetenkning}

Forholdet mellom medisin og kirurgi fra midten av 1700-tallet til begynnelsen av 1800-tallet er ikke lett å avdekke. Det er også et omstridt medisinskhistorisk tema. Her er det bare anledning til å nevne to perspektiver.

I det ene perspektivet danner kirurgien en mønstervitenskap. Medisinere nærmet seg kirurgiens anatomiske sykdomsoppfatning og lot humoralpatologi vike for patologisk anatomi som medisinens fundament. I korthet innebar det at sykdom ble knyttet til bestemte organer eller vev i stedet for en ubalanse mellom de fire kroppsvæskene. I kjølvannet fulgte en voksende interesse for klinisk undervisning og en medisinsk 
undersøkelse og diagnostisering som var manuell og instrumentell $(9,28,29)$.

I det andre perspektivet hevdes det at opplysningstidens krav om vitenskapens sosiale nytte påførte den lærde medisinen et legitimitetstap og tvang medisinerne til å knytte sin profesjonelle identitet til sosial funksjon fremfor klassisk dannelse. En sammensmeltet teori og praksis ses som kjernen i den nye profesjonsidentiteten, og det understrekes at praksis ble forstått som anvendt vitenskap, ikke som erfaringsbasert håndverk $(2,30)$. Kirurgiens innflytelse på medisinen blir ikke underslått, men «kirurgiseringen» ses i lys av opplysningstidens omforming av legerollen.

Hans Møllers plan om en praktisk orientert, men vitenskapelig legeutdanning (21) kan leses i lys av opplysningstenkningen. Det er legeutdanningens sosiale nytte som opptar ham, og en nyttig lege måtte beherske praktisk kirurgi like mye som de fundamentale vitenskapene. Dette er i tråd med den ideelle legegjerningen som opplysningsfilosofen Denis Diderot (1713-83) - som Møller refererte til - beskrev i den franske encyklopedien (1751-72). Opplysningstenkningen gir også mening til professor Skjelderups utsagn om at målet med en medisinskkirurgisk undervisning var å utdanne «den duelige Læge» $(1$, s. 584). I en tid med økt medikalisering av liv og død hadde medisinen åpenbart mer å vinne på å nærme seg kirurgien enn den selv kunne gi i form av teoretiske spekulasjoner og formfullendt latin.

Opplysningsideologi til tross, etableringen av en felles universitetsutdanning for medisinere og kirurger lot vente på seg i mange land. Blant de medisinske og kirurgiske elitene var det lenge et ønske om å bevare medisin og kirurgi som selvstendige profesjoner, selv om begge innså betydningen av en legevitenskap som omfattet begge fagområdene. Dette kom kanskje klarest til uttrykk i England. Der førte legenes, fremfor alt medisinernes, profesjonelle selvhevdelse til at medisin og kirurgi ennå ved utgangen av 1800-tallet var nokså selvstendige profesjoner.

\section{En stående, men skjør forening}

Norge var tidlig ute med å forene medisinsk og kirurgisk utdanning og dermed oppheve medisin og kirurgi som atskilte yrkeskategorier. Overgangen til et medisinskkirurgisk fellesskap var selvsagt ikke brå, aller minst i praksisfeltet. Den formelle sammensveisingen gjorde det imidlertid ikke bare legitimt å praktisere både medisin og kirurgi, men skapte også en forventning om at den enkelte yrkesutøveren skulle beherske begge deler. Etter hvert opphørte også det formelle skillet mellom medisinske og kirurgiske embeter i det offentlige legevesenet. I Norge ble de sivile legeembetene i distriktene - land- eller amtsfysikatene og distriktskirurgikatene - omdøpt til distriktslegeembeter i 1828 (18).
Etableringen av et medisinskkirurgisk studium reduserte, men opphevet ikke, forskjellen mellom medisinsk og kirurgisk praksis. Etter hvert fikk forskjellen konsekvenser for den praktiske undervisningen. I Det medisinske fakultets første studieplan fra 1826 het det at legekunsten hadde fått et omfang som gjorde det nødvendig å dele den praktiske undervisningen $\mathrm{i}$ «den indvendige Therapie og den u d ve n d i g e». Dette rokket likevel ikke ved oppfatningen av medisinstudiet som enhetlig. Fortsatt skulle studentene følge undervisningen i legevitenskapens «fundamentale Grene» og alle grenenes «anvendte Dele» (31, s. 189).

I siste halvdel av 1800-tallet ble forskjellen mellom medisinsk og kirurgisk praksis opplevd som større, fordi kirurgien - med sine nye bedøvelsesmidler og sterile operasjonsmetoder - ble mer teknisk, kompleks og vågal. Reseksjon erstattet bruddog sårbehandling som en dominerende kirurgisk praksis. Indre organer ble fjernet i et så stort omfang at perioden ca. 1870-1914 er blitt kalt den moderne kirurgiens anatomiske periode. Tross en felles medisinskkirurgisk utdanning kviet stadig flere leger seg for å praktisere moderne kirurgi, mens leger som helt viet seg til kirurgi, begynte å se på seg selv som legefellesskapets elite og erobret flere indremedisinske sykdommer. Dette førte ofte til temperamentsfulle møter i Det norske medicinske Selskab i Kristiania, men truet ikke det profesjonsfellesskapet som var blitt skapt gjennom en felles universitetsutdanning for medisinere og kirurger. Nå artet motsetningene seg ikke som en konflikt mellom to yrker, men som en strid om indremedisinens og kirurgiens grenser blant yrkesbrødre. Striden vedvarte inntil Den norske lægeforening iverksatte en spesialistutdanning i kirurgi og indremedisin samt 11 andre fagområder, først for profesjonsforeningens medlemmer i Kristiania (1917), fra 1919 for medlemmer over hele landet.

\section{Oppgitte interessekonflikter: Ingen}

\section{Litteratur}

1. Skjelderup M. Det medicinske Studium ved Det Kongelige Frederiks Universitet (fra Begyndelsen af Aaret 1824 til Udgangen af Aaret 1826). Budstikken 1827, nr. 73-79: 577-632.

2. Broman TH. The transformation of German academic medicine 1750-1820. Cambridge: Cambridge University Press, 1996.

3. Ackerknecht EH. Medicine at the Paris hospital 1794-1848. Baltimore, MD: The Johns Hopkins University Press, 1967.

4. Bonner TN. Becoming a physician. Medical education in Britain, France, Germany, and the United States, 1750-1945. Baltimore, MD: The Johns Hopkins University Press, 1995

5. Bullough VL. The development of medicine as a profession. The contribution of the medieval university to modern medicine. Basel: S. Karger, 1966

6. Moseng OG. Ansvaret for undersåttenes helse 1603-1850. Det offentlige helsevesen i Norge 1603-2003. Bd 1. Oslo: Universitetsforlaget, 2003
7. Norrie G. Kirurger og Doctores. Et kritisk bidrag til lægeuddannelsens historie i Danmark før 1800 København: Levin \& Munksgaard, 1929

8. Carøe K. Medicinalordningens historie indtil Sundhedskollegiets oprettelse 1803. København: Nyt Nordisk Forlag, 1917

9. Gelfand T. Professionalizing modern medicine. Paris surgeons and medical science and institutions in the 18th century. London: Greenwood Press, 1980.

10. Norrie G. Theatrum Anatomico-Chirurgicum I. 1736-1744. København: Levin \& Munksgaard 1931

11. Norrie G. Theatrum Anatomico-Chirurgicum II. 1745-1785. København: Levin \& Munksgaard, 1932

12. Norrie G. Chirurgisk Academis Historie: Acade miets Stiftelse. København: Brødrene Salmonsen, 1896

13. Norrie G. Kirurgisk akademis historie 1785-1803. København: Schultz, 1923

14. Huerkamp C. Der Aufstieg der Ärzte im 19. Jahrhundert. Vom gelehrten Stand zum professionellen Experten: Das Beispiel Preussens. Göttingen Vandenhoeck \& Ruprecht, 1985.

15. Skydsgaard MA. Ole Bang og en brydningstid i dansk medicin. Århus: Århus Universitetsforlag 2006

16. Norrie G. Kirurgisk akademis historie 1803-1841. København: Schultz, 1923

17. Lie AK. Radesykens tilblivelse. Historien om en sykdom. Doktoravhandling: Oslo: Det medisinske fakultet, Universitetet i Oslo/Unipub, 2008.

18. Utheim J. Det civile Lægevæsens Udvikling før 1814. I: Indstilling fra den kongelige Lægekommis sion af 1898. Kristiania, 1903.

19. Horn, HI. Betænkninger over Herr professor Egger's Plan til et universitet for Norge. København, 1794

20. Allerunderdanigst Forestilling fra Den Kongelige Direction for Universitetet og de Lærde Skoler. 12.4.1811. I: Historiske samlinger udgivne af Den Norske Historiske Kildeskriftkommision. Tredie Bind. Christiania, 1914: 407-26.

21. Møller H. Forsøg til en plan til et universitet i Norge. Christiania, 1795.

22. Kongeligt aabent Brev ang. et Universitets Anlæg og Indretning i Kongeriget Norge. 10de April 1812. I: Holst C, red. Det kongelige Norske Frederiks Universitets Legater, samt Akstykker, vedkommende Universitetets Oprettelse, dets Donationer m.m. Christiania, 1851: 89-92

23. Resolution af 24de Marts 1812. I: Holst C, red. Det kongelige Norske Frederiks Universitets Legater, samt Akstykker, vedkommende Universitetets Oprettelse, dets Donationer m.m. Christiania, 1851: 184-6

24. Allerunderdanigst Forestilling fra Commissionen for det Norske Universitets Anlæg og Indretning, den 15de Martii 1812. I: Holst C, red. Det kongelige Norske Frederiks Universitets Legater, samt Akstykker, vedkommende Universitetets Oprettelse, dets Donationer m.m. Christiania, 1851 187-236.

25. Skjelderup M. Det medicinske Studium ved Norges Universitet. Budstikken 1824 nr. 26-29: 201-232. nr. 30-33: 233-264

26. Weisz G. Constructing the medical elité in France: The creation of the Royal Academy of Medicine 1814-20. Med Hist 1986; 30: 419-43.

27. Larsen $\emptyset$. Legestudent i hovedstaden - medisin på stadig nye måter. Oslo: Gyldendal Akademisk, 2002

28. Temkin 0 . The role of surgery in the rise of modern medical thought. Bull Hist Med 1951; 25: 248-59.

29. Reiser SJ. Medicine and the reign of thechnology. Cambridge: Cambridge University Press, 1978.

30. Hannaway C, La Berge A, red. Constructing Paris medicine (Clio Medica 50). Amsterdam: Editions Rodolphi, 1998

31. Hopstock H. Det anatomiske institut 23. januar 1815-23. januar 1915. Christiania: Aschehoug. 1915

Manuskriptet ble mottatt 24.9. 2009 og godkjent 5.11. 2009. Medisinsk redaktør Anne Kveim Lie. 